Article

\title{
Fabrication and Characterization of a Ruthenium Nitride Membrane for Electrochemical pH Sensors
}

\author{
Yi-Hung Liao ${ }^{1,2}$ and Jung-Chuan Chou ${ }^{1.3, *}$
}

1 Graduate School of Engineering Science and Technology, National Yunlin University of Science and Technology / 123, 3 sec. University, Douliou, Yunlin, Taiwan R.O.C.;

E-Mail: liaoih@tit.edu.tw

2 Department of Information Management, Transworld of Institute of Technology / 1221, Jen-Nang Rd., Chia-Tong Li, Douliou, Yunlin, Taiwan R.O.C.

3 Graduate School of Electronic Engineering, National Yunlin University of Science and Technology/ 123, 3 sec. University, Douliou, Yunlin, Taiwan R.O.C.

* Author to whom correspondence should be addressed; E-Mail: choujc@yuntech.edu.tw; Tel.: 886-5-534-2601 ext. 2101; Fax: 886-5-532-1719

Received: 12 February 2009; in revised form: 27 March 2009 / Accepted: 31 March 2009/ Published: 9 April 2009

\begin{abstract}
The $\mathrm{pH}$ sensing and nonideal characteristics of a ruthenium nitride (RuN) sensing membrane $\mathrm{pH}$ sensor were investigated. RuN thin films were deposited from a $99.9 \%$ ruthenium target on p-type silicon substrates using radio frequency (r.f.) sputtering with $\mathrm{N}_{2}$ gas. Subsequently, the nanometric structure and surface morphology of RuN thin films were determined. The sensitivity of the RuN sensing membrane $\mathrm{pH}$ sensor was 58.03 $\mathrm{mV} / \mathrm{pH}$, obtained from $\mathrm{I}_{\mathrm{D}}-\mathrm{V}_{\mathrm{G}}$ curves with a current-voltage (I-V) measurement system in standard buffer solutions from $\mathrm{pH} 1$ to $\mathrm{pH} 13$ at room temperature $\left(25^{\circ} \mathrm{C}\right)$. Moreover, the nonideal characteristics of the RuN sensing membrane, such as temperature coefficient, drift with light influence, drift rate and hysteresis width, etc. were also investigated. Finally, the sensing characteristics of the RuN membrane were compared with titanium nitride (TiN), aluminum nitride (AlN) and silicon nitride $\left(\mathrm{Si}_{3} \mathrm{~N}_{4}\right)$ membranes.
\end{abstract}

Keywords: Ruthenium nitride; ion selective electrode; temperature coefficient; light influence; drift rate; hysteresis width. 


\section{Introduction}

In the past to recent years, the measurement of $\mathrm{pH}$ values has been a very important parameter in different application fields, for example: clinical diagnosis, wastewater and environment monitoring, etc. The ion sensitive field effect transistor (ISFET) was first presented by Bergveld in 1970 [1]. Many hydrogen ion sensing gate materials are used for ISFET, for instance, a-Si:H [2, 3], $\mathrm{Si}_{3} \mathrm{~N}_{4}[4], \mathrm{Ta}_{2} \mathrm{O}_{5}$ [4], $\mathrm{Al}_{2} \mathrm{O}_{3}$ [4], a- $\mathrm{WO}_{3}$ [5], $\mathrm{SnO}_{2}$ [6] and PMT [7]. These ion sensing thin films are prepared using different methods, such as sputtering [5], sol-gel [6,7], thermal evaporation [8] and plasma enhanced chemical vapor deposition (PECVD) [9, 10]. Subsequently, Van der Spiegel et al. [11] published the first paper on the extended gate field effect transistor (EGFET) in 1983. The configuration of the EGFET was separated into two parts: the sensing membrane and a metal oxide semiconductor field effect transistor (MOSFET) structure. The sensing thin films of ISFET or EGFET were almost always metal oxides. In this study, we will introduce other sensing membranes, the metal nitrides. Many researchers have discussed nitride thin films, which include titanium nitride (TiN) [12-16], hafnium nitride (HfN) [14], aluminum nitride (AlN) [17-21], indium nitride ( $\mathrm{InN}$ ) [22], chromium nitride (CrN) [23], zirconium nitride $(\mathrm{ZrN})$ [24], gallium nitride $(\mathrm{GaN})$ [25], ruthenium nitride $(\mathrm{RuN})$ [26, 27] and silicon nitride $\left(\mathrm{Si}_{3} \mathrm{~N}_{4}\right)$ [28, 29], etc. There are many literature reports [5, 10, 19, 26, 30-35] which discuss the temperature and light nonideal characteristics of ISFETs. Nitride membranes used for $\mathrm{pH}$ measurement have been reported previously [15-17, 19]. Lei et al. [15] adopted titanium nitride as a pH-sensitive material based on an extended gate ISFET. Chin et al. [16] also introduced a titanium nitride membrane used as a sensing material in $\mathrm{pH}$ sensors with EGFET. Chiang et al. [17, 19] reported an $\mathrm{AlN} / \mathrm{SiO}_{2}$ gate $\mathrm{pH}$ ion sensitive field effect transistor used for hydrogen ion concentration measurement and investigated the drift, hysteresis and temperature effects of the aluminum nitride membrane. Chou et al. [36] reported a separative structure extended gate $\mathrm{H}^{+}$-ion sensitive field effect transistor (SEGFET) with tin oxide $\left(\mathrm{SnO}_{2}\right)$ thin films made using sol-gel technology. The SEGFET structure was similar to the EGFET one, but the former is easier to fabricate and package, and has lower costs than ISFET structures. In this study, ruthenium nitride (RuN) thin films deposited on silicon substrates were prepared from a ruthenium target using the r.f. sputtering technique. The sensitivity of the RuN sensing membrane with the SEGFET was determined using a Keithley 236 current-voltage (I-V) measurement system. The drift with light influence, temperature coefficient, drifts rate and hysteresis width of the nonideal characteristics of RuN-based $\mathrm{pH}$ sensor were also investigated with a voltage-time (V-T) measurement system. In addition, the experimental results are compared with those of other nitride and oxide $\mathrm{pH}$-sensing materials.

\section{Experimental}

\subsection{Materials and regents}

Silicon wafer was used as the substrate of the ruthenium nitride sensing membrane $\mathrm{pH}$ sensor device. The silicon substrate was p-type, (100)-oriented, provided by the National Nano Device Laboratories (NDL, Taiwan). The RuN sensing membrane was prepared using a sputtering system and deposited onto the silicon substrate maintained at $25^{\circ} \mathrm{C}$ by radio frequency sputtering from a 2 -inch- 
diameter, 1/4 inch-thickness, 99.99\% purity ruthenium target. Before sputter deposition, the silicon substrate and ruthenium target were placed in the chamber, and then sputtering was carried out. Acetone and methanol solvents were purchased from ACROS Co. Ltd. (USA) and used for cleaning the silicon wafer. All regents were analytical grade and used without further purification.

\subsection{Fabrication of RuN sensing membranes}

The silicon substrates were cleaned ultrasonically in acetone and methanol alternately for 15 minutes, leached in deionized (D.I.) water, and then dried with $\mathrm{N}_{2}$ gas. In this work, a total operating sputtering pressure of 10 mtorr in Ar-gas-mixed $\mathrm{N}_{2}$ for 1 hour was used. The gas flow ratio of the Ar: $\mathrm{N}_{2}$ was 1:2 (15:30 in sccm). The radio frequency power was $100 \mathrm{~W}$, at $13.56 \mathrm{MHz}$. After the RuN was sputtered, the silicon wafer substrate was cleaned with deionized water and cut about $0.5 \mathrm{~cm} \times 0.5 \mathrm{~cm}$ size. A conducting wire was bonded to the substrate with silver glue and then baked at $130^{\circ} \mathrm{C}$ for 30 minutes. The substrate was simple to package with epoxy resin and a $2 \mathrm{~mm}$ x $2 \mathrm{~mm}$ sensing window was left to detect hydrogen ion concentrations. Ruthenium metal is a good conductive material, and according to [26], ruthenium nitride has low resistivity as a conductive material.

\subsection{Morphology of ruthenium nitride analysis}

To examine the surface morphology of ruthenium nitride, a scanning electron microscope (SEM) and a scanning probe microscope (SPM) were used. A Philips XL-40FEG field emission scanning electron microscope was used to reveal the cross-section and nanometric structures of the ruthenium nitride thin film and a tapping mode atomic force microscope (Digital Instrument NS3a controller with D3100 stage) was used to measure the surface morphology of ruthenium nitride thin film.

\subsection{Measurement systems}

A Keithley 236 semiconductor parameter analyzer was utilized to measure the current-voltage characteristics of the RuN thin film $\mathrm{pH}$-sensitive SEGFET in $\mathrm{pH}=1,3,5,7,9,11$ and 13 standard buffer solutions. The current voltage (I-V) measurement system is shown in Figure. 1. The gate of MOSFET is connected to the RuN pH sensor. The drain and source of MOSFET are connected to the current measuring unit of the Keithley 236. The $\mathrm{RuN}$ sensing membrane $\mathrm{pH}$ sensor device and an $\mathrm{Ag} / \mathrm{AgCl}$ reference electrode were immersed into the different standard buffer solutions, respectively and placed inside a dark box to eliminate any light-induced effects. The commercial $\mathrm{Ag} / \mathrm{AgCl}$ reference electrode provided a constant potential during the whole measurement process. The drainsource voltage $\left(\mathrm{V}_{\mathrm{DS}}\right)$ was maintained constant at $0.2 \mathrm{~V}$ and the $\mathrm{V}_{\mathrm{G}}$ voltage was increased from 0 to $6 \mathrm{~V}$ while the drain-source current $\left(\mathrm{I}_{\mathrm{DS}}\right)$ was measured. The sensitivity of $\mathrm{RuN}$ sensing membrane $\mathrm{pH}$ sensor was obtained from the $\mathrm{I}_{\mathrm{D}}-\mathrm{V}_{\mathrm{G}}$ curves. 
Figure 1. I-V measurement system used for the RuN pH-sensing membrane with separative extended gate field effect transistor.

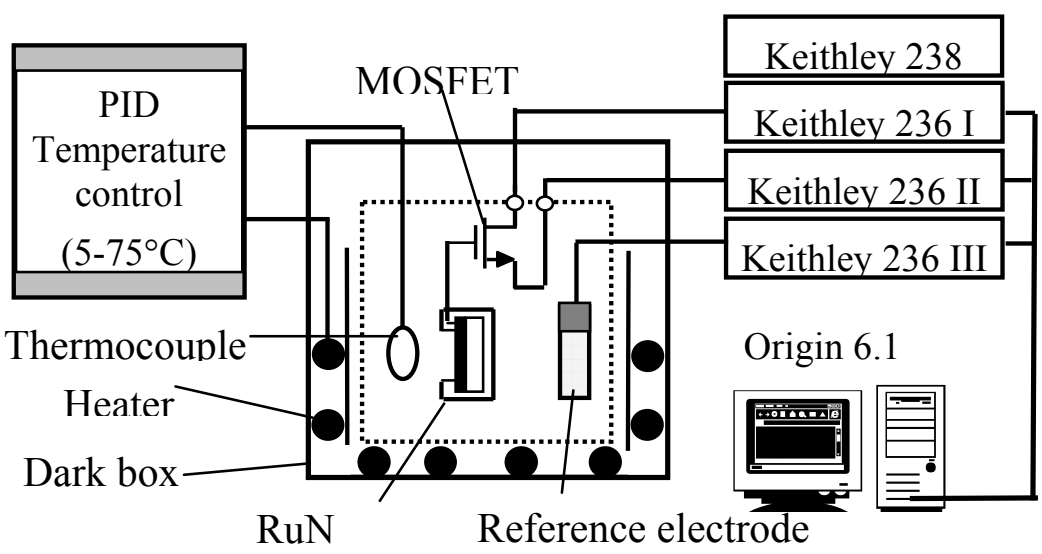

Figure 2. V-T measurement system used for the RuN sensing membrane $\mathrm{pH}$ sensor.

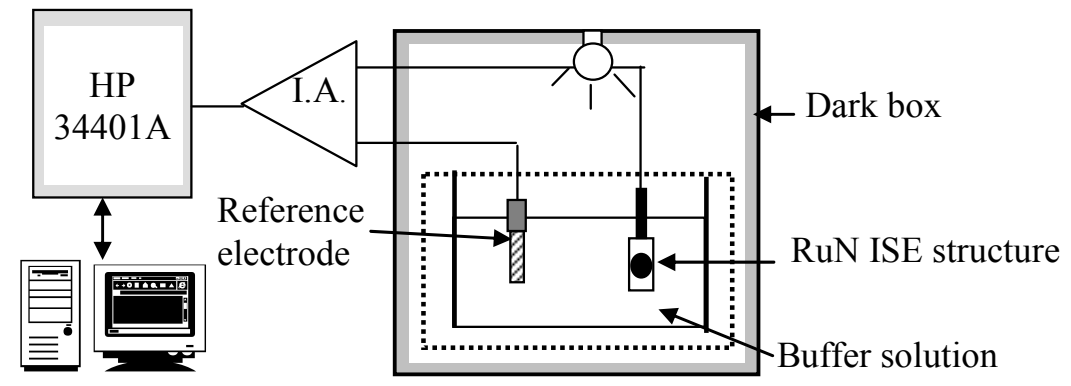

The voltage-time measurement system is shown in Figure 2. The V-T measurement system consisted of the PID temperature controller, an instrument amplifier (I.A.) as readout circuit and a HP 34401A multi-function digital meter voltage-time recorder. They were used to determine the drift and hysteresis behaviors of the $\mathrm{RuN}$ sensing membrane $\mathrm{pH}$ sensor. The sensor and reference electrode were immersed in the $\mathrm{pH}$ buffer solution for 12 hours, then the output voltage of the $\mathrm{pH}$ sensor was recorded; then the drift rate is the slope of the output voltage with respect to time, where the time is greater than five hours. The drift with light influence of the RuN sensing membrane test structures was investigated by illumination using a $110 \mathrm{~V}$ light bulb in a measurement chamber. The voltage variation was monitored with the light in the measurement environment on and off.

\section{Results and Discussion}

\subsection{Materials analysis of ruthenium nitride thin films}

In this study, the membrane was the same as that used in our previous research [26], which showed that the thin film deposited using the sputtering system was ruthenium nitride. An Electron Spectroscopy for Chemical Analysis (ESCA) experiment was done on the RuN thin film and the results were consistent with the ESCA of ruthenium nitride thin film. The ESCA analysis exhibited XPS spectra which showed obvious $\mathrm{Ru}, \mathrm{N}$ and $\mathrm{O}$ peaks. Moreover, the cross-section of ruthenium 
nitride measured from the scanning electron spectroscope (SEM) image in our previous research [38] showed a membrane thickness of ca. $574.2 \mathrm{~nm}$. We used an atom force microscope (AFM) to investigate the morphological structure of the ruthenium nitride thin film. A field emission scanning electron spectroscope (FE-SEM) was used to investigate the nanometric structure of ruthenium nitride thin film. Figure 3 shows the typical SEM image pattern of the ruthenium nitride thin film deposited on the silicon substrate. The RuN surface in the 80,000 times SEM image shows surface compactness and some clustered nano particles. Scanning probe microscope experiments in tapping mode of operation was employed in order to determine the morphological structure of ruthenium nitride thin films.

Figure 3. Nanometric structures of ruthenium nitride thin films by SEM measurement.

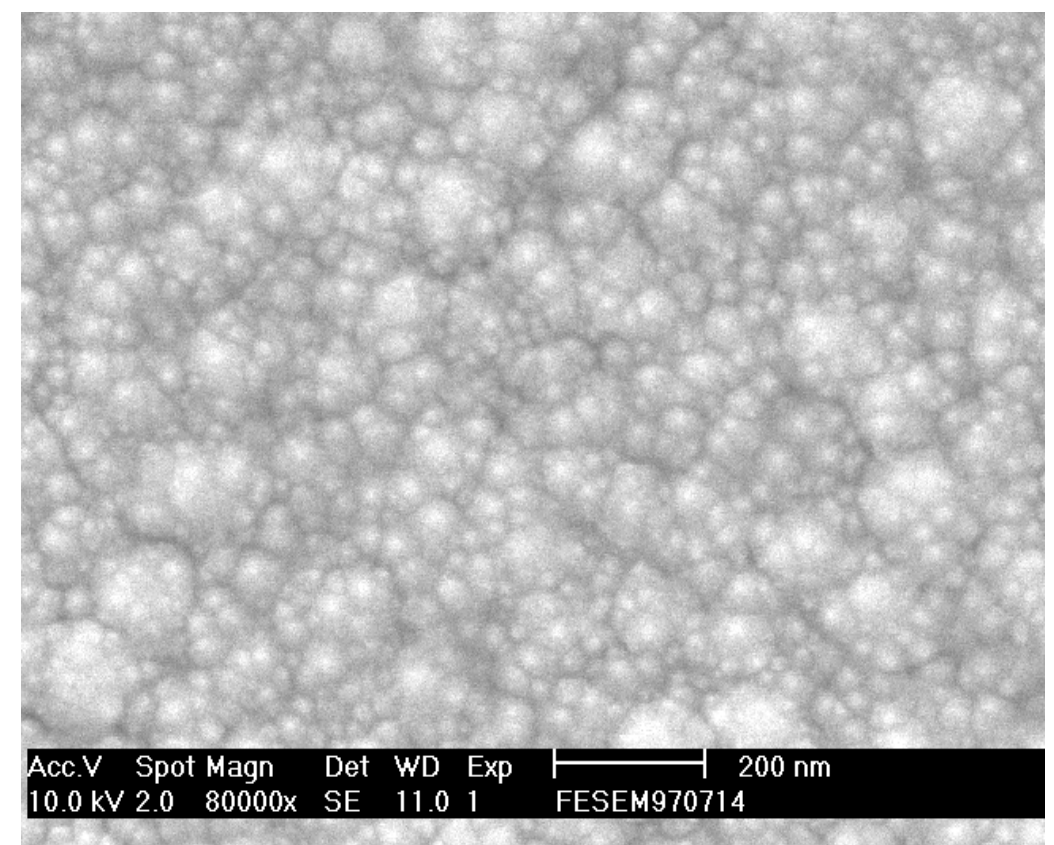

Figure 4 shows the morphology of the silicon wafer after the deposition of ruthenium nitride using the sputtering system. It displays the atomic force microscope image of the ruthenium nitride thin film, and the profile shows that the measured average ( $\mathrm{Ra}$ ) and root mean square (Rrms) of the roughness analysis of the ruthenium nitride particles are $2.42 \mathrm{~nm}$ and $3.12 \mathrm{~nm}$, respectively. The nano scale of the surface can increase the reaction area with hydrogen ion analyte solution.

\subsection{Characteristics of ruthenium nitride membrane $\mathrm{pH}$ sensor}

\subsubsection{I-V characteristic and $\mathrm{pH}$ sensitivity}

Figure 5 shows the $I_{D}-V_{G}$ characteristic curves of the RuN sensing membrane $p H$ sensor in the $\mathrm{pH}$ range from $\mathrm{pH} 1$ to $\mathrm{pH} 13$ at room temperature $\left(25^{\circ} \mathrm{C}\right)$. According to [28], as the $\mathrm{pH}$ value increases, the surface potential of the ion-sensing membrane decreases. Therefore, the $I_{D}-V_{G}$ curve was shifted positively as the $\mathrm{pH}$ value increased. The inset of Figure 5 was obtained from the I-V curves of Figure 5. In Figure 1, the MOSFET was operated at a drain current of $200 \mu \mathrm{A}$, and the $\mathrm{V}_{\mathrm{G}}$ voltages were 
between $1.975 \mathrm{~V}$ and $2.656 \mathrm{~V}$ in standard buffer solutions from $\mathrm{pH} 1$ to $\mathrm{pH} 13$. The $\mathrm{V}_{\mathrm{G}}$ versus $\mathrm{pH}$ curves were obtained, and the sensitivity was defined as $\Delta \mathrm{V}_{\mathrm{G}} / \Delta \mathrm{pH}$ and was shown in the inset of Figure 5. Therefore, we can obtain the sensitivity of RuN sensing membrane is $58.03 \mathrm{mV} / \mathrm{pH}$ in the buffer solutions from $\mathrm{pH} 1$ to $\mathrm{pH}$ 13. Chin et al. [16] presented a titanium nitride membrane EGFET $\mathrm{pH}$ sensor and its sensitivity was $57.27 \mathrm{mV} / \mathrm{pH}$ in buffer solutions between $\mathrm{pH} 2$ and $\mathrm{pH} 10$. Chiang et al. [17] reported that the sensitivities of AlN pH electrodes were $48-57.25 \mathrm{mV} / \mathrm{pH}$ in the buffer solutions range of $\mathrm{pH}=1-11$. We can deduce that the sensitivity and $\mathrm{pH}$ measurement range of the $\mathrm{RuN}$ membrane $\mathrm{pH}$ sensor is superior to the AlN, TiN and $\mathrm{Si}_{3} \mathrm{~N}_{4}$ membranes $\mathrm{pH}$ sensors. Comparisons of the sensitivity and $\mathrm{pH}$ range with the other nitrides and different thin films are listed in Table 1.

Figure 4. Surface morphology of ruthenium nitride thin films by AFM measurement

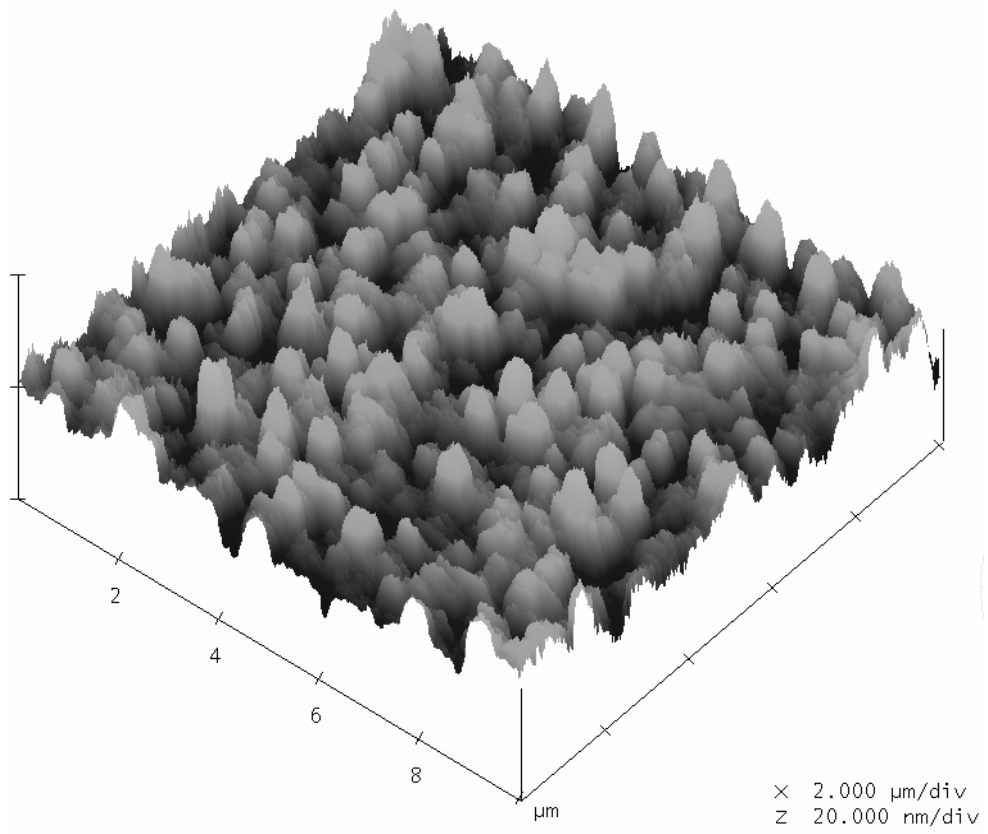

Figure 5. I-V and sensitivity curves of ruthenium nitride thin film $\mathrm{pH}$ sensor.

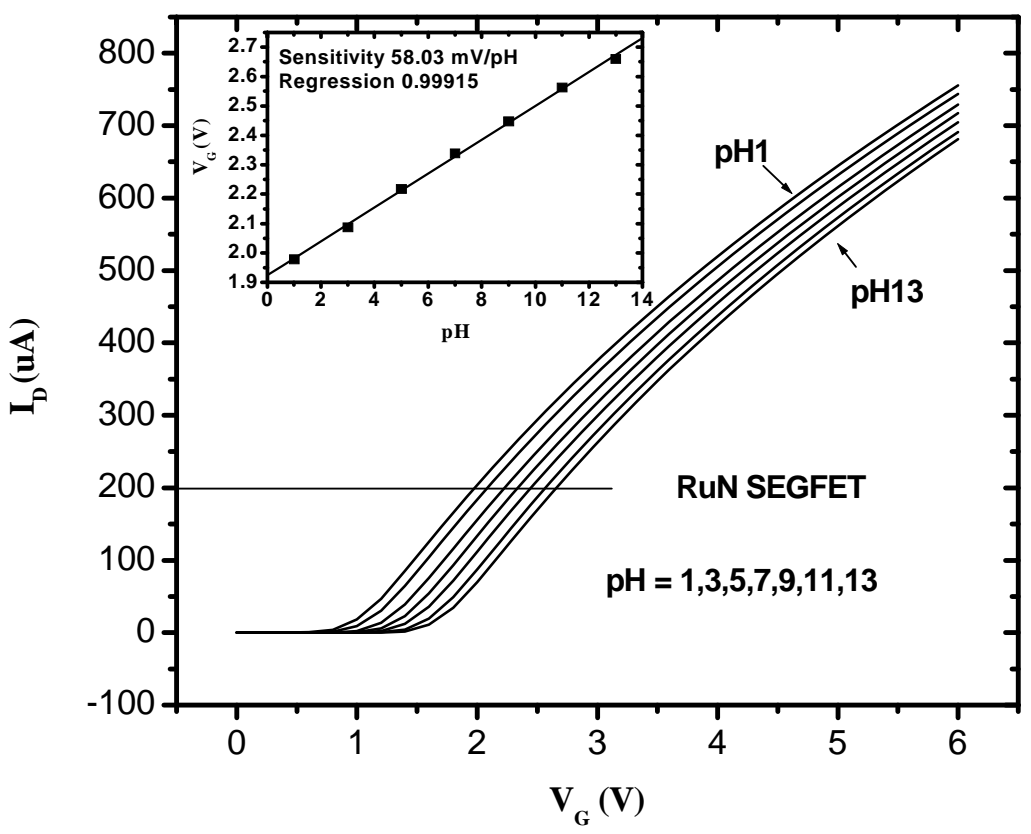


Table 1. Comparison of sensitivity, $\mathrm{pH}$ range and drift rate with other nitrides and different thin films.

\begin{tabular}{|c|c|c|c|c|c|c|}
\hline Thin film & $\begin{array}{l}\text { Preparation } \\
\text { method }\end{array}$ & $\begin{array}{c}\text { Drift rate } \\
(\mathrm{mV} / \mathrm{h})\end{array}$ & $\begin{array}{l}\text { Device } \\
\text { structure } \\
\end{array}$ & pH range & $\begin{array}{c}\text { Sensitivity } \\
(\mathrm{mV} / \mathrm{pH})\end{array}$ & Ref. \\
\hline RuN & Sputtering & 2.15 & SEGFET & pH1-13 & 58.03 & This study \\
\hline $\mathrm{Si}_{3} \mathrm{~N}_{4}$ & PECVD & 1.0 & ISFET & pH1-13 & $46-56$ & {$[4]$} \\
\hline $\mathrm{AlN}$ & Sputtering & 2.43 & ISFET & pH1-11 & $48-57.25$ & {$[17]$} \\
\hline TiN & Sputtering & - & EGFET & $\mathrm{pH} 2-10$ & 57.27 & [16] \\
\hline $\mathrm{a}-\mathrm{WO}_{3}$ & Sputtering & 15.7 & ISFET & pH1-7 & $45-56$ & {$[5]$} \\
\hline $\mathrm{SnO}_{2}$ & Sputtering & 9.1 & EGFET & $\mathrm{pH} 2-12$ & 58 & {$[10]$} \\
\hline $\mathrm{SnO}_{2}$ & $\begin{array}{l}\text { Thermal } \\
\text { Evaporation }\end{array}$ & 28 & ISFET & $\mathrm{pH} 2-12$ & 58 & {$[8]$} \\
\hline $\mathrm{SnO}_{2}$ & Sol-gel & 6.73 & ISFET & pH1-9 & 57.36 & [6] \\
\hline PMT & Sol-gel & 0.4 & ISFET & pH2-12 & $58-59$ & {$[7]$} \\
\hline a-Si:H & PE-LPCVD & 6.53 & ISFET & pH1-7 & 52.3 & {$[3]$} \\
\hline $\mathrm{Ta}_{2} \mathrm{O}_{5}$ & PECVD & 0.5 & ISFET & $\mathrm{pH} 2-12$ & $56-57$ & {$[4]$} \\
\hline $\mathrm{Al}_{2} \mathrm{O}_{3}$ & PECVD & $0.1-0.2$ & ISFET & pH1-13 & $53-57$ & {$[4]$} \\
\hline $\mathrm{TiO}_{2}$ & MOCVD & 11.9 & $\mathrm{TiO}_{2} / \mathrm{SiO}_{2} / \mathrm{Si}$ & pH3-11 & 57.2 & [34] \\
\hline
\end{tabular}

\subsection{Nonideal characteristics of ruthenium nitride membrane $\mathrm{pH}$ sensor}

The electrochemical $\mathrm{pH}$ sensors, such as ion selective electrode (ISE), EGFET and ISFET have exhibited some primary nonideal characteristics. The drift with light influence, temperature coefficient, drift rate and hysteresis width of ruthenium nitride membrane $\mathrm{pH}$ sensor were studied.

\subsubsection{Temperature coefficient}

The response of an ideal $\mathrm{pH}$ electrode is defined by the Nernst equation as follows:

$$
E=E_{0}-2.3 \frac{R T}{n F} \log a_{H}^{+}
$$

where:

$\mathrm{E}$ is total potential (in $\mathrm{mV}$ ) developed between the sensing and reference electrode;

$\mathrm{E}_{0}$ is standard potential of the electrode at $a_{H}^{+}=1 \mathrm{~mol} / \mathrm{L}$;

$\mathrm{R}$ is Gas constant;

$\mathrm{T}$ is temperature;

$\mathrm{n}$ is valency of ion;

$\mathrm{F}$ is Faraday constant;

$a_{H}^{+}$is activity of the hydrogen ion in solution.

The term $2.3 \mathrm{RT} / \mathrm{nF}$ is referred to as the Nernst slope. Table 2 shows the changes in Nernstian slope for the $\mathrm{RuN}$ electrode at increasing temperatures. The I-V characteristics measurements of the $\mathrm{RuN} \mathrm{pH}$ sensor were carried out for $\mathrm{pH} 1 \sim \mathrm{pH} 13$ buffer solutions at $5{ }^{\circ} \mathrm{C}, 15^{\circ} \mathrm{C}, 25^{\circ} \mathrm{C}, 35^{\circ} \mathrm{C}, 45^{\circ} \mathrm{C}$ and $55^{\circ} \mathrm{C}$, 
respectively. The sensitivity value increased with increased operation temperature. From the data of Table 2, the temperature coefficient of sensitivity of the $\mathrm{RuN} \mathrm{pH}$ sensor is $0.168 \mathrm{mV} / \mathrm{pH}^{\circ} \mathrm{C}$. To investigate the temperature coefficient of $\mathrm{RuN}$ sensing membrane $\mathrm{pH}$ sensor the temperature compensation data was used. Furthermore, the temperature coefficients in $\mathrm{pH}$ electrochemical sensors with various sensing materials, such as $\mathrm{TiN}$, and $\mathrm{Si}_{3} \mathrm{~N}_{4}$ have been also reported $[16,17,35]$. Chin et al. [16] described that the temperature coefficient of sensitivity of $\mathrm{TiN} \mathrm{pH}$ sensor is $0.180 \mathrm{mV} / \mathrm{pH}^{\circ} \mathrm{C}$. Chiang et al. [17] reported that the temperature coefficient of sensitivity of the AlN pH sensor is 0.130 $\mathrm{mV} / \mathrm{pH}^{\circ} \mathrm{C}$. Chou et al. [35] presented that the temperature coefficient of sensitivity of $\mathrm{Si}_{3} \mathrm{~N}_{4} \mathrm{pH}$ sensor is $0.150 \mathrm{mV} / \mathrm{pH}^{\circ} \mathrm{C}$.

Table 2. Sensitivity of RuN thin film $\mathrm{pH}$ sensor at various temperatures.

\begin{tabular}{ccccccc}
\hline Temperature $\left({ }^{\circ} \mathbf{C}\right)$ & $\mathbf{5}$ & $\mathbf{1 5}$ & $\mathbf{2 5}$ & $\mathbf{3 5}$ & $\mathbf{4 5}$ & $\mathbf{5 5}$ \\
\hline Sensitivity $(\mathrm{mV} / \mathrm{pH})$ & 55.51 & 57.47 & 58.03 & 60.52 & 62.35 & 64.04 \\
\hline
\end{tabular}

\subsubsection{Drift with light influence}

Voorthuyzen and Bergveld [33] were the first to investigate the slow response of the $\mathrm{Ta}_{2} \mathrm{O}_{5}$ gate ISFET after illumination. In this study, we investigated the drift with light influence characteristics of the $\mathrm{RuN}$ thin film $\mathrm{pH}$ sensor in the dark box and under constant light exposure, respectively. Our experiment was focused on the output voltage variation of the $\mathrm{pH}$ sensor after switching the light on and off. The experimental results are shown in Figure 6. When the light was switched on and off the output voltage of the RuN pH sensor varied with time. Then the $3.65 \mathrm{mV}$ variation amount of response voltage was obtained with light on and light off and this voltage will make a $0.063 \mathrm{pH}(3.65 \mathrm{mV} / 58.03$ $\left.(\mathrm{mV} / \mathrm{pH})^{-1}\right)$ variation.

Figure 6. Drift with light influence of $\mathrm{RuN}$ thin film $\mathrm{pH}$ sensor.

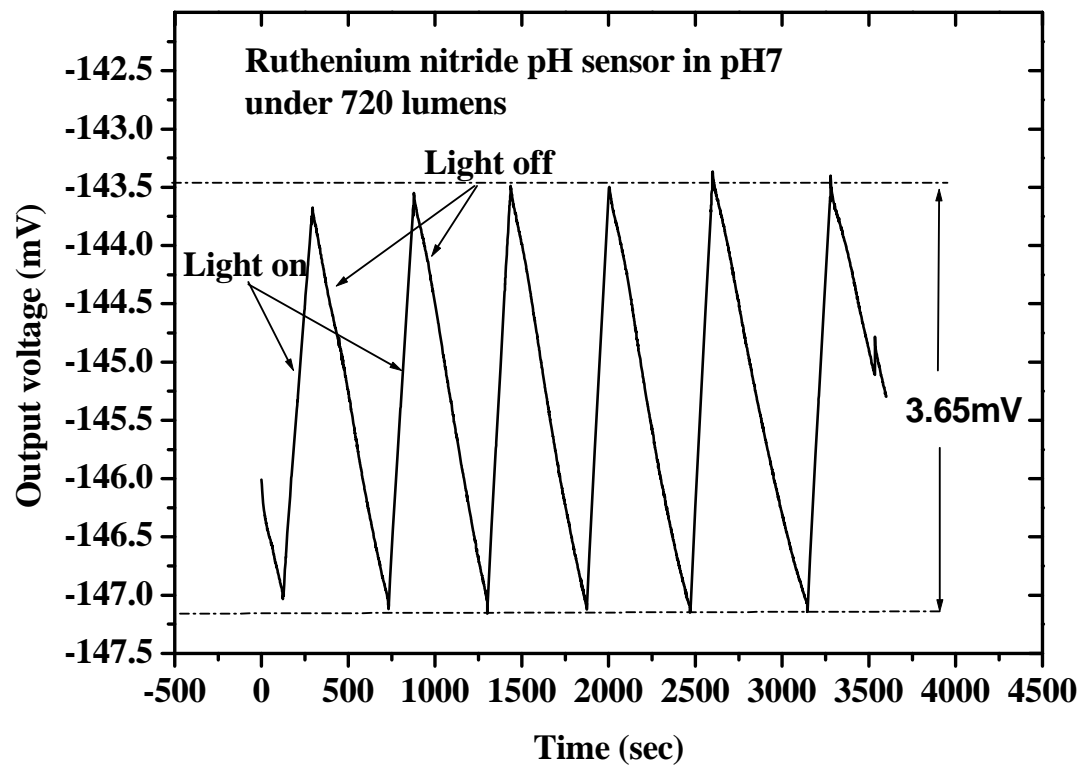




\subsubsection{Drift effect}

The drift phenomenon in $\mathrm{pH}$ electrochemical sensors with various sensing materials, such as a-Si:H, $\mathrm{Si}_{3} \mathrm{~N}_{4}, \mathrm{Al}_{2} \mathrm{O}_{3}, \mathrm{Ta}_{2} \mathrm{O}_{5}, \mathrm{AlN}$ and $\mathrm{SnO}_{2}$ has been discussed [3, 4, 6, 8, 10, 17]. According to Zhong et al. [37] the surface voltage response reaches a steady state after five hours with no $\mathrm{pH}$ variation. Therefore, we choose the measured data as representing a long term drift rate during 5-12 hours. The drift phenomenon shows that the output voltage of the RuN sensor device varies slowly with time. Drift behavior existed in the whole measurement process and could be characterized as a function of $\mathrm{pH}$ value. The V-T measurement system was used to measure the drift rate of the RuN sensing membrane $\mathrm{pH}$ sensor in $\mathrm{pH} 1,4,7,10,13$ standard buffer solutions. Figure 7 shows the drift rate of $\mathrm{RuN} \mathrm{pH}$ sensor in $\mathrm{pH} 4$ buffer solution after measuring for 12 hours. The calculation of drift rate is $1.69 \mathrm{mV} / \mathrm{h}$, which is the voltage difference from 18,000 sec (5 hours) to 43,200 sec (12 hours), divided by the time duration ( 7 hours). According to the experimental results, we can obtain the drift rate with percent error of the RuN sensing membrane $\mathrm{pH}$ sensor, which are shown in Table 3. It is obvious that the higher the hydrogen ion concentration, the lower the drift rate was. The cause is that at lower $\mathrm{H}^{+}$ concentrations, the higher $\mathrm{pH}$ value, and the ion size of $\mathrm{H}^{+}$is smaller than $\mathrm{OH}^{-}$. Therefore, the drift speed of $\mathrm{H}^{+}$is quicker than for $\mathrm{OH}^{-}$. The drift rates were compared with other nitrides and different thin films as shown in Table 1.

Table 3. Drift rates of RuN thin film for the $\mathrm{pH}$ sensor.

\begin{tabular}{cccccc}
\hline pH & pH 1 & pH 4 & pH 7 & pH 10 & pH 13 \\
\hline Drift rate $(\mathrm{mV} / \mathrm{h})$ & $1.09 \pm 0.5 \%$ & $1.69 \pm 0.8 \%$ & $2.15 \pm 1.4 \%$ & $2.51 \pm 3.9 \%$ & $3.17 \pm 4.2 \%$ \\
\hline
\end{tabular}

Figure 7. Drift rate of RuN pH sensor in $\mathrm{pH} 4$ buffer solution for measuring 12 hours.

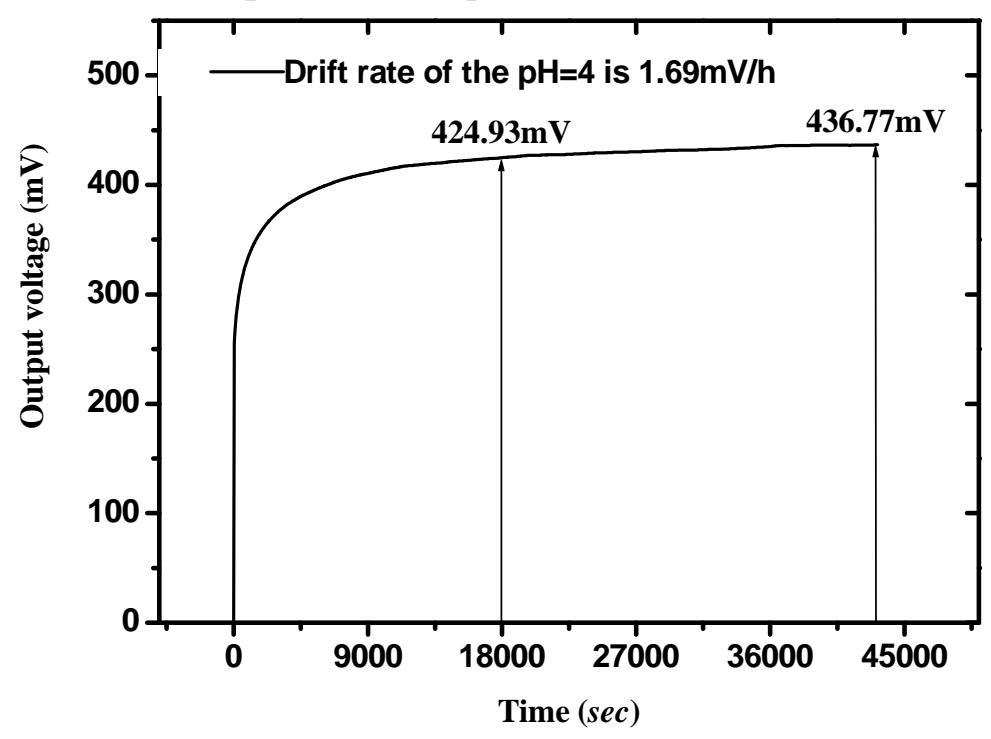

\subsubsection{Hysteresis effect}

The RuN pH sensor was measured many times in the same $\mathrm{pH}$ buffer solution to see the difference of output voltages. This phenomenon we called hysteresis or memory effect. According to Bousse et 
al. [32] the hysteresis of $\mathrm{pH}-\mathrm{ISFETs}$ could be regarded as a delay of the $\mathrm{pH}$ response. The hysteresis only occurs at the buffer solution and insulator interface, and is related with the buffer solution composition. The V-T measurement system was used to measure the hysteresis width of the RuN sensing membrane $\mathrm{pH}$ sensor in different $\mathrm{pH}$ buffer solutions with a $\mathrm{pH}$ loop cycle and 10 minutes loop time. According to the experimental results, the hysteresis widths of the RuN sensing membrane $\mathrm{pH}$ sensor are $2.7 \mathrm{mV}$ and $9.1 \mathrm{mV}$ in $\mathrm{pH} \mathrm{7-4-7-10-7} \mathrm{and} \mathrm{pH}$ 7-10-7-4-7, respectively. We also compared the hysteresis width with the different thin films, as shown in Table 4.

Table 4. Comparison of hysteresis widths for the different thin films.

\begin{tabular}{|c|c|c|c|c|}
\hline Thin film & $\begin{array}{c}\text { Hysteresis width } \\
(\mathrm{mV})\end{array}$ & Loop path & Loop time (min) & Ref. \\
\hline \multirow{2}{*}{$\mathrm{RuN}$} & 2.7 & $\mathrm{pH} 7-4-7-10-7$ & 10 & \multirow{2}{*}{ In this study } \\
\hline & 9.1 & $\mathrm{pH} 7-10-7-4-7$ & 10 & \\
\hline $\mathrm{TiN}$ & 0.5 & $\mathrm{pH} 7-4-7-10-7$ & 10 & {$[16]$} \\
\hline AlN & 1.0 & $\mathrm{pH} 7-3-7-11-7$ & 16 & {$[17]$} \\
\hline $\mathrm{Si}_{3} \mathrm{~N}_{4}$ & 2.0 & $\mathrm{pH} 7-3-7-11-7$ & 1024 & {$[39]$} \\
\hline \multirow{2}{*}{ a-Si:H } & 17.9 & pH 3-1-3-5-3 & - & \multirow{2}{*}[2]{} \\
\hline & 1.5 & pH 3-5-3-1-3 & - & \\
\hline \multirow{2}{*}{$\mathrm{a}-\mathrm{WO}_{3}$} & 1.5 & pH 3-5-3-1-3 & - & \multirow{2}{*}[5]{} \\
\hline & 26.0 & $\mathrm{pH} 4-7-4-1-4$ & 10 & \\
\hline \multirow{2}{*}{$\mathrm{SnO}_{2}$} & 1.3 & pH 4-1-4-7-4 & 13 & \multirow{2}{*}{ [6] } \\
\hline & 3.74 & pH 5-1-5-9-5 & 17 & \\
\hline PMT & 1.0 & $\mathrm{pH} 7-4-7-10-7$ & 25 & {$[7]$} \\
\hline $\mathrm{SnO}_{2}$ & 9.8 & PH 7-4-7-10-7 & 10 & {$[10]$} \\
\hline
\end{tabular}

\section{Conclusions}

In this study, we use the sputtering method to prepare a RuN sensing membrane as an electrochemical $\mathrm{pH}$ sensor. The sensing characteristics of the ruthenium nitride membrane were stable in $\mathrm{pH}$ buffer solutions between $\mathrm{pH} 1$ and $\mathrm{pH}$ 13. From the experimental results, the sensitivity of the RuN sensing membrane $\mathrm{pH}$ sensor is $58.03 \mathrm{mV} / \mathrm{pH}$. Therefore, we conclude that the RuN membrane $\mathrm{pH}$ sensor is better than $\mathrm{TiN}, \mathrm{AlN}$ and $\mathrm{Si}_{3} \mathrm{~N}_{4}$ membrane ones with regards to $\mathrm{pH}$ range and sensitivity, respectively. The temperature coefficient of the $\mathrm{RuN} \mathrm{pH}$ sensor is $0.168 \mathrm{mV} / \mathrm{pH}^{\circ} \mathrm{C}$ from $5{ }^{\circ} \mathrm{C}$ to $55^{\circ} \mathrm{C}$. Light exposure resulted in a $0.063 \mathrm{pH}$ variation for the $\mathrm{RuN} \mathrm{pH}$ sensor. The drift rates of the $\mathrm{RuN}$ sensing membrane $\mathrm{pH}$ sensor are $1.69 \mathrm{mV} / \mathrm{h}, 2.15 \mathrm{mV} / \mathrm{h}$ and $2.51 \mathrm{mV} / \mathrm{h}$ at $\mathrm{pH} 4, \mathrm{pH} 7$ and $\mathrm{pH} 10$, respectively and the hysteresis widths of the $\mathrm{pH}$ 7-4-7-10-7 and $\mathrm{pH}$ 7-10-7-4-7 cycles are $2.7 \mathrm{mV}$ and $9.1 \mathrm{mV}$, respectively. 


\section{Acknowledgements}

This study is supported by the National Science Council, The Republic of China, under contract NSC 97-2221-E-309-001 and NSC 97-2221-E-224-058-MY3.

\section{References}

1. Bergveld, P. Development of an ion sensitive solid-state device for neurophysiological measurements. IEEE Trans. Biomed. Eng. 1970, BME-17, 70-71.

2. Chou, J.C.; Hsiao, C.N. The hysteresis and drift effect of hydrogenated amorphous silicon for ISFET. Sens. Actuat. B 2000, 66, 181-183.

3. Chou, J.C.; Hsiao, C.N. Drift behavior of ISFET with a-Si: $\mathrm{H}-\mathrm{SiO}_{2}$ gate insulator. Mater. Chem. Phys. 2000, 63, 270-273.

4. Matsuo, T.; Esashi, M. Method of ISFET fabrication. Sens. Actuat. B 1981, 1, 77-96.

5. Chiang, J.L.; Jan, S.S.; Chou, J.C.; Chen, Y.C. Study on the temperature effect, hysteresis and drift of pH-ISFET devices based on amorphous tungsten oxide. Sens. Actuat. B 2001, 76, 624-628.

6. Chou, J.C.; Wang, Y.F. Preparation and study on the drift and hysteresis properties of the tin oxide gate ISFET by the sol-gel method. Sens. Actuat. B 2002, 86, 58-62.

7. Jan, S.S.; Chen, Y.C.; Chou, J.C. Effect of $\mathrm{Mg}^{2+}$-dopant on the characteristics of lead titanate sensing membrane for ion-sensitive field-effect transistors. Sens. Actuat. B 2005, 108, 883-887.

8. Yin, L.T.; Chou, J.C.; Chung, W.Y.; Sun, T.P.; Hsiung, S.K. Analysis of nanocrystalline coatings of tin oxides on glass by atomic force microscopy. Sens. Actuat. B 2000, 71, 106-111.

9. Jakobson, C.G.; Feinsod, M.; Nemirovsky, Y. Low frequency noise and drift in Ion Sensitive Field Effect Transistors. Sens. Actuat. B 2000, 68, 134-139.

10. Chou, J.C.; Wang, Y.F. Temperature characteristics of a-Si:H gate. ISFET, Mater. Chem. Phys. 2001, 70, 107-111.

11. Van der Spiegel, J.; Lauks, I.; Chan, D. Babic, P. Study on extended gate field effect transistor with tin oxide sensing membrane. Sens. Actuat. B 1983, 4, 291-298.

12. Meng, L.J.; Azevedo, A.; dos Santos, M.P. Deposition and properties of titanium nitride films produced by dc reactive magnetron sputtering. Vacuum 1995, 46, 233-239.

13. Sánchez, O.; Hernández-Vélez, M.; Navas, D.; Auger, M.A.; Baldonedo, J.L.; Sanz, R.; Pirota, K.R.; Vázquez, M. Functional nanostructured titanium nitride films obtained by sputtering magnetron. Thin Solid Films 2006, 495, 149-153.

14. Berg, G.; Friedrich, C.; Broszeit. E.; Kloos, K.H. Comparison of foundational properties of r.f.sputtered TiNx and HfNx coating on steel substrates. Surf. Coat. Technol. 1995, 74-75, 135-142.

15. Lei, Z.C.; Chou, J.C.; Chin, Y.L.; Chung, W.Y.; Sun, T.P.; Hsiung, S.K. A novel pH-sensitive material based on titanium nitride for extended gate ISFET. In The 2000 Annual Conference of the Chinese Society for Material Science, I-Shou University, Kaohsiung, Taiwan, November 2425, 2000.

16. Chin, Y.L.; Chou, J.C.; Lei, Z.C.; Sun, T.P.; Chung, W.Y.; Hsiung, S.K. Titanium nitride membrane application to extended gate field effect transistor $\mathrm{pH}$ sensor. Jpn. J. Appl. Phys. 2001, 40, 6311-6315. 
17. Chiang, J.L.; Chou, J.C.; Chen, Y.C.; Liau, G.S. Cheng, C.C. Drift and hysteresis effects on $\mathrm{AlN} / \mathrm{SiO}_{2}$ gate $\mathrm{pH}$ ion-sensitive field-effect transistor. Jpn. J. Appl. Phys. 2003, 42, 4973-4977.

18. Lin, Y.R.; Wu, S.T. Growth of aluminum nitride films at low temperature. J. Cryst. Growth 2003, 252, 433-439.

19. Chiang, J.L.; Chen, Y.C.; Chou, J.C.; Cheng, C.C. Temperature effect on $\mathrm{AlN} / \mathrm{SiO}_{2}$ gate pH-ionsensitive field-effect transistor devices. Jpn. J. Appl. Phys. 2002, 41, 541-545.

20. Kishi, K.; Ooishi, Y.; Noma, H.; Ushijima, E.; Ueno, N.; Akiyama, M.; Tabaru, T. Measurement of output voltage of aluminum nitride thin film as a pressure sensor at high temperature. J. Eur. Ceram. Soc. 2006, 26, 3425-3430.

21. Vacandio, F.; Massiani, Y.; Gravier, P.; Rossi, S.; Bonora, P.L.; Fedrizzi, L. Improvement of the electrochemical behaviour of AIN films produced by reactive sputtering using various underlayers. Electrochem. Acta 2001, 46, 3827-3834.

22. Jain, A.; Raghavan, S.; Redwing, J.M. Evolution of surface morphology and film stress during MOCVD growth of InN on sapphire substrates. J. Cryst. Growth 2004, 269, 128-133.

23. Engel, P.; Schwarz, G.; Wolf, G.K., Characterization of chromium nitride films prepared by ionbeam-assisted deposition. Surf. Coat. Technol. 1999, 112, 286-290.

24. Gruss, K.A.; Zheleva, T.; Davis, R.F.; Watkins, T.R. Characterization of zirconium nitride coatings deposited by cathodic arc sputtering. Surf. Coat. Technol. 1998, 107, 115-124.

25. Tripathy, S.; Wang, L.S.; Chua, S.J. Characterization of GaN layers grown on silicon-on-insulator substrates. Appl. Surf. Sci. 2006, 253, 236-240.

26. Chou, J.C.; Liu, S.I.; Chen, S.H. Sensing characteristics of ruthenium films fabricated by radio frequency sputtering. Jpn. J. Appl. Phys. 2005, 44, 1403-1408.

27. Moreno-Armenta, M.G.; Diaz, J.; Martinez-Ruiz, A.; Soto, G. Synthesis of cubic ruthenium nitride by reactive pulsed laser ablation. J. Phys. Chem. Solids 2007, 68, 1989-1994.

28. Woias, P.; Meixner, L.; Fröistl, P. Slow pH response effects of silicon nitride ISFET sensors. Sens. Actuat. B 1998, 48, 501-504.

29. Garde, A.; Alderman, J.; Lane. W. Development of a pH-sensitive ISFET suitable for fabrication in a volume production environment. Sens. Actuat. B 1995, 26-27, 341-344.

30. Ito, Y. Stability of ISFET and its new measurement protocol. Sens. Actuat. B 2000, 66, 53-55.

31. Van Den Vlekkert, H.; Bousse, L.; De Rooij, N.F. The temperature dependence of the surface potential at the $\mathrm{Al}_{2} \mathrm{O}_{3}$ /electrolyte interface. J. Colloid Interface Sci. 1998, 122, 336-345.

32. Bousse, L.; Van Den Vlekkert, H.; De Rooij, N.F. Hysteresis in $\mathrm{Al}_{2} \mathrm{O}_{3}$-gate ISFETs. Sens. Actuat. B 1990, 2, 103-110.

33. Voorthuyzen, J.A.; Bergveld, P. Photoelectric effects in $\mathrm{Ta}_{2} \mathrm{O}_{5}-\mathrm{SiO}_{2}$-Si structures. Sens. Actuat. B 1990, 1, 350-353.

34. Shin, P.K. The pH-sensing and light-induced drift properties of titanium dioxide thin films deposited by MOCVD. Appl. Surf. Sci. 2003, 214, 214-221.

35. Chou, J.C.; Tseng, Y.N. The temperature effect of $\mathrm{Si}_{3} \mathrm{~N}_{4}$ gate for the commercial Beckman $\Phi^{\mathrm{TM}} 110 \mathrm{pH}$ ISFET. In Proceedings of the 1999 Annual Conference of the Chinese Society for Materials Science, Industrial Technology Research Institute, Hsinchu, Taiwan, R.O.C., December 26-27, 1999. 
36. Chou, J.C.; Kwan, P.K.; Chen, Z.J. $\mathrm{SnO}_{2}$ separative structure extended gate $\mathrm{H}^{+}$-ion sensitive field effect transistor by sol-gel technology and the readout circuit developed by source follower. Jpan. J. Appl. Phys. 2003, 42, 6790-6794.

37. Zhong, Y.; Ohao, S.; Lin, T. Drift characteristics of pH-ISFET output. Chin. J. Semicond. 1994, $12,838-843$.

38. Liu, S.I. Study on the preparation, measurement and readout circuit of the bio-medicine sensor by the sputtering of ruthenium. M. S. Dissertation, Institute of Electronic Engineering at National Yunlin University of Science and Technology: Yunlin, Taiwan, 2004.

39. Bousse, L.; Mostarshed, S.; Van Der Schoot, B.; De Rooij, N.F., Comparison of the hysteresis of $\mathrm{Ta}_{2} \mathrm{O}_{5}$ and $\mathrm{Si}_{3} \mathrm{~N}_{4} \mathrm{pH}$-sensing insulators. Sens. Actuat. B 1994, 17, 157-164.

(C) 2009 by the authors; licensee Molecular Diversity Preservation International, Basel, Switzerland. This article is an open-access article distributed under the terms and conditions of the Creative Commons Attribution license (http://creativecommons.org/licenses/by/3.0/). 